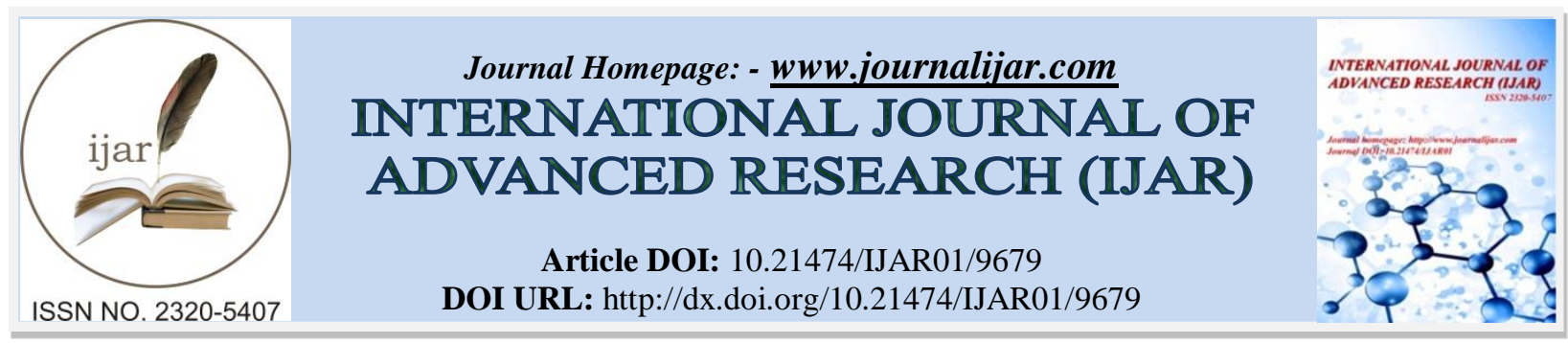

RESEARCH ARTICLE

\title{
CLINICAL EVALUATION OF ROLE OF AMRUTADYA TAILA MATRA BASTI IN THE MANAGEMENT OF VATARAKTA: A CASE STUDY.
}

\author{
Rajesh Km. Dharua ${ }^{1}$ and Alok Km. Srivastava ${ }^{2}$. \\ 1. P.G. Scholar, Dept. of Panchkarma, Rishikul Campus, U.A.U, Haridwar. \\ 2. Professor, Dept. of Panchkarma, Main Campus, U.A.U, Haridwar.
}

\section{Manuscript Info}

Manuscript History

Received: 06 July 2019

Final Accepted: 08 August 2019

Published: September 2019

Key words:-

Vatarakta, Khavaigunya, Raktavaha Srotas, Tridosha, Matra Basti.

\begin{abstract}
Vatarakta is a disease related with Khavaigunya found in Raktavaha Srotas which includes vitiated Vata and blood. Small joints of feet and hands are mainly affected in Vatarakta. Vata being pre dominant among the Tridosha has the potential to cause more serious and long term diseases than the other two. The classical texts lay down ample of importance to the functions and characteristics of Vata. At the same time, Rakta being the foremost body tissue also play an important role in sustaining the healthy life of the person. Vatarakta is an illness where both Vata and Rakta are afflicted by distinct etiological factors. Description of Vatarakta has been done since Samhita Kala. According to Aacharya Charaka, clinical features of Vatarakta are different according to site. To identify an alternative \& safer management, Matra Basti Karma was selected for the study to see its effect on Vatarakta. 20 patients were selected on the basis of inclusion criteria of Vatarakta \& were given treatment. There was found to be significantly reduction in symptoms like Kandu, Daha, Ruja, Toda, Sandhi shotha, Stabdhata, Sparshasahishnuta and Raga.
\end{abstract}

Copy Right, IJAR, 2019,. All rights reserved.

\section{Introduction:-}

Vatarakta is common presentation which is characterized by severe pain, tenderness, inflammation and burning sensation in the affected joints ${ }^{1}$. Vatarakta is a disease related with Khavaigunya found in Raktavaha Srotas which includes vitiated Vata and blood. Small joints of feet and hands are mainly affected in Vatarakta. ${ }^{2}$ The disease characterized by the abnormally of Rakta Dhatu due to morbidity of Vata Dosha is called as Vatarakta ${ }^{3}$. Nidana or Hetu in the opinion of Ayurvedic scholars is the main causative factor of the disease. Acharya Sushruta has clearly mentioned that Nidana Parivarjana is the nutshell of treatment. In each and every disease all the etiological factors precipitating the disease should be abandoned. Excessive use of Lavana, Amla, Katu, kshara, Snigdha and Ushna Ahara, ingestion of food before the digestion of previous meal, excessive use of Klinna, Shushka things, excessive use of meat of aquatic and marshy animals, Pinyaka, Muli, intake of Kulthi, Masha and other Shaka, sugarcane, use of Dahi, Kanji, Sauvira, Sukta, Takra, Surasava are some of the important causative factors of the disease Vatarakta in the opinion of Acharya Charaka ${ }^{4}$. According to site of origin Acharya Charaka, Chakrapani Dutta, Yogratnakar have further classified Vatarakta as Uttana Vatarakta and Gambhira Vatarakta. Other Ayurvedic Acharyas have not mentioned these two varieties of Vatarakta. In spite of these one more variety of Vatarakta i.e. Ubhaya Vatarakta has been described by Acharya Charaka. Regarding Sadhya- Asadhyata of Vatarakta, Acharya Charaka has pointed that if Vatarakta is newly originated and without complications originating from vitiation or provocation of a single

Corresponding Author:-Rajesh Km. Dharua.

Address:-P.G. Scholar, Dept. of Panchkarma, Rishikul Campus, U.A.U, Haridwar. 
Dosha, then it is Sadhya (Curable) condition. If it is caused by vitiation of Tridosha as well as associated with complications, it becomes Asadhya or incurable.

\section{Material \& methods:-} गुडूचीमधुकंह्रस्व चैतत्तैलाग्यममृताह्रयम || (च. चि. २९/९०३-९०९)

Taila is main Dravya to pacify Vata Dosha, as described. So, Taila can be used in the form of Matra Basti.

\section{Contents of Amrutadya Taila:}

1. Oil Used: Til Taila

2. Kwatha Dravyas Guduchi, Mulethi, Laghu Panchmool (Shaalparni, Prishnparni, Brihti, Kantkari, Gokshur), Punarnava, Raasna, Erandamool, Jeevniya Gana, Bala, Kol, Bilwa, Yava, Masha, Kultha, Gambhari Pushpa.

3. Prakshepa dravyas:Chandana, Khas, Nagkesar, Tejpatra, Hrisva Ela, Agaru, Kootha, Tagar

Therapy Review: Basti

Simply it is assumed that due to self-etiology Vata gets vitiated and lead to Rakta Dusti. Ultimately Rakta forms Avarana in channels of Vata and both gets mutually vitiated. Seats of Vata are mainly larger and smaller joints so, the joints are involved in this condition.

Treatment of Vatarakta described in various texts in mainly Basti Chikitsa.

नहिवस्तिसमंकिंचिदवातरक्तचिकित्सितम्॥ (च. चि. २९/८८)

Matra Basti can be administered at all times and in all seasons. It is recommended for daily use in those affected with Vata Vikara.

Observations \& result:

Pre Treatment Observations:

Total number of patients registered:

\begin{tabular}{|l|l|}
\hline TYPE & NO. OF PATIENTS \\
\hline COMPLETE & 16 \\
\hline LAMA & 4 \\
\hline TOTAL & 20 \\
\hline
\end{tabular}

\section{Stastical analysis:-}

The information collected on the basic of observations was subjected to statistical analysis using Graph Pad Instat, Software version 3.10 and SPSS Software. For intra group comparison of subjective criteria Wilcoxon test and for objective criteria Paired-t test was applied.

\begin{tabular}{|c|c|c|c|c|c|c|}
\hline \multirow[t]{2}{*}{ Chief complaints } & \multicolumn{2}{|l|}{ Median } & \multirow{2}{*}{$\begin{array}{l}\text { Mean } \\
\text { Diff }\end{array}$} & \multirow[t]{2}{*}{$\%$} & \multirow[t]{2}{*}{$\mathbf{W}$} & \multirow[t]{2}{*}{$\mathbf{P}$} \\
\hline & BT & AT & & & & \\
\hline KANDU & 1 & 0 & 1 & 100 & -10.000 & 0.125 \\
\hline DAHA & 1 & 0 & 1 & 100 & -10.000 & 0.125 \\
\hline RUJA & 1 & 0 & 1 & 100 & -120.000 & $<0.001$ \\
\hline TODA & 1 & 0 & 1 & 100 & -6.000 & 0.250 \\
\hline SANDHISOTHA & 1.5 & 0.5 & 1 & 66.66 & -10.000 & 0.125 \\
\hline SHABDHATA & 1.285714 & 0.285714 & 1 & 77.77 & -28.000 & 0.016 \\
\hline SPARSHASAHISHNUTA & 1.6 & 0.6 & 1 & 62.5 & -15.000 & 0.063 \\
\hline TWAKVAIVARNYA & 2 & 1 & 1 & 50 & -3.000 & 0.500 \\
\hline RAGA & 1.75 & 0.75 & 1 & 57.14286 & -10.000 & 0.125 \\
\hline
\end{tabular}




\section{Discussion:-}

Discussion on Disease:

Vatarakta is a disease of vitiated Vata along with vitiated Rakta. In Charaka Samhita it is mentioned that Vata due to subtleness (Sukshmatva) and pervasiveness (Sarva-Sarvatva) and Rakta due to liquidity (Dravatva) and flowing nature (Saratva), circulates through the body, through blood vessels (Raktavaha-Srotasa), gets obstructed in Sandhies (Joints) due to torsion nature of it course in joint, Vata and Rakta again agitated there. After SthanSamshraya or localization and in combination with Pitta etc. causes different type of Shool(Pain) according to the predominance of Doshas. The cardinal feature of Vatarakta is the sudden onset of joint pain (mostly in MTP joint) along with the inflammation of the joint.

\section{Discussion on Matra Basti:}

Basti therapy is considered as prime among all the therapeutic measures, especially for management of Vatavyadhies, and some physicians accept it as a complete therapeutic measure. Basti Dravyas can act as Vatahara, Shulahara, Shothahara, Srotoshodhaka, Yogavahi, Agnideepaka, and Rasayana. Our Acharyas have considered the rectum (Guda) as the root of the body (Mula of Sharira). According to Acharya Charaka: 'As a tree irrigated in its root attains blue branches with beautiful tender leaves, flowers and fruits in time, and attains a big stature, so too the man with unctuous enema given through the rectum ${ }^{7}$. On the action of Basti, Vagabhatta $^{8}$ says the Virya of Basti is conveyed to Apana and then to Samana Vata, which may regulate the function of Agni. It then goes to Udana, Vyana, and Prana, thus providing its efficacy all over the body. At the same time Basti by pacifying Vata, restores the disturbed Kapha and Pittaat their original seats and thus helps in breaking the pathogenesis.

\section{Conclusion:-}

Thus, Basti Karma exerts a largely systemic action exerting local action in Gastrointestinal tract by operating through large intestine involving enteric nervous system. Basti Karma can activate the autonomic nervous system and thereby help in the evacuation of Basti Dravya. Hence, it can be concluded that Amrutadya Taila Matra Basti could be a better treatment modality in Vatarakta.

\section{References:-}

1. Agnivesha, charaka Samhita, Vaidya yadavji trikamji acharya, chaukamba orientalia, Varanasi, 5th edition; 2009.

2. Sushruta, sushruta Samhita, chaukamba orientalia, Varanasi, 7th edition, nidana sthana; 2008.

3. Charaka, Bala D, Shastri RD, Acharya YT, editors. Siddhisthana. 5th ed. Varanasi: Chaukhambha Sanskrit series; Charaka Samhita,Agnivesha; p. 682.

4. Agnivesha, charakasamhita- vidyotini tika edited by kasinath sastri \& Gorakhnath Chaturvedi, Chaukamba Bharti academy, Varanasi, edition reprinted 2009, cikitsasthana chapter 29/5-7, PP 820.

5. Agnivesha, charakasamhita- vidyotini tika edited by kasinath sastri \& Gorakhnath Chaturvedi, Chaukamba Bharti academy, Varanasi, edition reprinted 2009, cikitsasthana chapter 29/103-109.

6. Agnivesha, charakasamhita- vidyotini tika edited by kasinath sastri \& Gorakhnath Chaturvedi, Chaukamba Bharti academy, Varanasi, edition reprinted 2009, cikitsasthana chapter 29/88.

7. Charaka, Bala D, Shastri RD, Acharya YT, editors. Siddhisthana. 5th ed. Varanasi: Chaukhambha Sanskrit series; Charaka Samhita,Agnivesha; p. 682.

8. Shastri L, editor. Siddhidsthana. 1st ed. Baidyanath Ayurved Bhavan Pvt. Ltd; 1989. Ashtanga Samgraha with Sarvanga Sundari Vyakhya; p. 1105. 